УДК 811.111'42

DOI https://doi.org/10.24919/2308-4863/34-5-29

Зоряна ЯЦІВ,

orcid.org/0000-0002-1736-1705

аспірант кафедри іноземних мов для природничих факультетів Львівського начіонального університету імені Івана Франка

(Львів, Україна) zyatsiv@gmail.com

\title{
ДО ПИТАННЯ ІДЕНТИФІКАЦІЇ АВТОРСЬКОЇ КОЛОНКИ ЯК ПУБЛЦИСТИЧНОГО ЖАНРУ
}

\begin{abstract}
Статтю присвячено проблемі ідентифікації авторської колонки як самостійного публіцистичного жанру, яким активно послуговуються автори медійних текстів. Потреба у висвітленні даної проблематики зумовлена множинністю підходів до трактування сутності колонки загалом. Одні дослідники розглядають колонку як форму подачі матеріалу, форму коментаря або різновид есе, інші виділяють ї̈ як самостійний жанр, а треті узагалі не згадують у свойх жанрових системах. Відтак, метою пропонованої статті є здійснення комплексного аналізу авторської колонки на прикладі колонки редактора. Даний тип колонки є жанром реалізації валеологічного дискурсу (дискурсу здорового способу життя), зокрема, його різновиду - професійно-непрофесійного, учасниками якого є фахівці і широкий загал. Реалізація поставленої мети передбачає обтрунтування правомірність виокремлення авторської колонки як окремого жанру, виявлення і опис ї̈ зовнішніх та внутрішніх ідентифікаторів та встановлення основних жанрових ознак.

Під час дослідження запропоновано характеристику колонки редактора крізь призму ї оформлювальних (зовнішніх) та змістових (внутрішніх) ідентифікаторів. Виявлено такі зовнішні особливості, як назва рубрики, періодичність виходу, місие у випуску, обсяг тексту, портрет, ім'я та підпис автора тексту. Серед внутрішніх ознак виділено авторський стиль викладу, використання автобіографічних моментів, риторичних запитань, імітування живого діалогу з читачем та композиційну побудову. Встановлено, щьо характерними жанровими ознаками авторської колонки є: образ автора та його авторське бачення, діалогічність повідомлення та орієнтація на інтерактивність. Функція колонки редактора полягає в авторському осмисленні валеологічної проблематики з опорою на дані досліджень та ознайомленні реципієнтів зі змістом цілого випуску із посиланням на відповідний матеріал у ньому. Доведено, щзо колонка редактора є самостійним публіцистичним жанром зі свойми особливостяли та варіативністю, яка продиктована авторським підходом, політикою видання та соціокультурним контекстом.
\end{abstract}

Ключові слова: колонка, авторська колонка, колонка редактора, жанр, персоналізачія, професійно-непрофесійний валеологічний дискурс.

Zoriana YATSIV, orcid.org/0000-0002-1736-1705 Postgraduate Student at the Department of Foreign Languages for Natural Studies Ivan Franko National University of Lviv (Lviv, Ukraine) zyatsiv@gmail.com

\section{TO THE QUESTION OF AUTHOR'S COLUMN IDENTIFICATION AS A JOURNALISTIC GENRE}

The article is devoted to the problem of the author's column identification as a separate journalistic genre widely-used by the authors of media texts. The need to discuss this problem is predetermined by the multiple understanding of the notion «column» in general. Some researchers consider author's column a form of material presentation, commentary or type of essay, others single it out as a separate genre, but some do not mention it in their genre systems at all. Thus, the purpose of this article is to perform a detailed analysis of author's column on the basis of editor's column. This type of column is a genre of valeological discourse (healthy lifestyle discourse), especially its professional-non-professional type where experts and general public are the communicants. The major task of this study is to prove the expediency of singling out author's column as a separate genre, detect and describe its outer and inner characteristics, identify its main genre-forming factors and offer its definition.

The editor's column characteristics are suggested through its formal (outer) and content (inner) parameters. Heading, edition frequency, place, text volume, author's photo, name and signature are its outer characteristics. Among the inner markers there are author's style, autobiographical references, rhetorical questions, live dialogue imitation and composition. The main genre-forming factors of editor's column are the following: author's image and vision, 
dialogicity of the message and focus on interactivity. The function of editor's column consists in revealing the author's vision of the topic with reference to different studies and familiarizing the recipients with the contents of the issue in a condensed form. Notwithstanding some slight discrepancies in the analyzed texts, it was proved that author's column is a separate journalistic genre. It is characterized by the unity of content, style and composition, high level of intimacy and personalization, both dominant characteristics and variety which is dictated by the author's approach, editorial policy and sociocultural context.

Key words: column, author's column, editor's column, genre, personalization, professional-non-professional valeological discourse.

Постановка проблеми. Сучасні 3МІ функціонують в умовах гострої конкуренції та боротьби за аудиторію, що викликає зміни у системі жанрів. Заради втримання існуючої та залучення нової аудиторії, вони ретельно добирають не лише контент, але й форму журналістських текстів, в яких відчутною є тенденція до персоналізації викладу. «Автор перестає бути знеособленим ретранслятором інформації, яку він передає - він все очевидніше стає іiі інтерпретатором. Точка зору конкретної особи сьогодні цікава сама по собі» (Кройчик, 2000: 126-127). Причина полягає у перенасиченості інформації фактами та деталями i, відповідно, потребі адресанта отримати пояснення, інтерпретацію, оскільки в потоці інформації він просто не встигає осмислити та проаналізувати їі. Як влучно зауважує А. Ю. Маєвська: «думаюча аудиторія шукає в інформаційному просторі автора, який розмірковує» (Маевская, 2011: 273). Таким чином, широкого розповсюдження набуває колумністика (від англ. column) - «сукупність творів, опублікованих за певний час в авторській колонціџ (Михайлин, 2013: 122). Поява авторської колонки - форми, в якій знаходимо бажане роз'яснення через призму авторської рефлексії колумніста (автора колонки) - свідчить про вдосконалення комунікативних стратегій у системі ЗМІ, що, своєю чергою, відображає очевидну орієнтацію на діалог зі своєю аудиторією (Ярцева, 2011: 3).

3 часу виникнення самого поняття (середина XVII ст., Свропа), колонка пройшла тривалу еволюцію від типографічного елементу оформлення для полегшення читання та виділення матеріалу до рубрики та окремого жанру, який сформувався у демократичних країнах, де в журналістиці панує свобода слова (США, Великобританія). Нині авторська колонка є однією з найпоширеніших та найпопулярніших текстових форм на сторінках як традиційних, так і мережевих 3МI. Однак недостатня розробленість цієї проблематики в сучасних філологічних (i журналістських) дослідженнях і питання правомірності виокремлення авторської колонки як окремого жанру визначають актуальність та необхідність проведення даної розвідки.
Аналіз досліджень. Авторська колонка неодноразово ставала об'єктом наукового розгляду українських, російських та європейських дослідників та все ж довкола неї досі точаться дискусії. Питання полягає в обгрунтованості виокремлення колонки як окремого жанру. Одні дослідники вважають, що колонка може існувати лише як форма подачі матеріалу (Гордеев, 2010) або узагалі не згадують у своїх жанрових системах (Тертычный, $2000)$, інші розглядають колонку як форму коментаря або різновид есе (Шостак, 1998), треті виокремлюють іï як самостійний жанр (Кройчик, 2000; Черникова, 2009).

На прикладі двох принципово відмінних моделей журналістики (англосаксонської та іспаномовної) проф. С. С. Ярцева доводить тезу про те, що «будь-які суперечки щодо того, чи $\epsilon$ колонка жанром, зводяться до одного: можливо вписати колонку в ту чи іншу жанрову систему чи ні, тобто - це питання класифікації» (Ярцева, 2011: 16). Варто наголосити, що в США та Європі, до прикладу, існують абсолютно різні жанрові класифікації, а власне в Європі превалює практичний підхід і під жанрами розуміють групи текстів, схожих за формою. Для англо-американської моделі журналістики жанр колонки - це, як підсумовує А. Ю. Маєвська, «радше тип художньої форми літературного твору, який характеризується спільністю структурно-композиційних та стилістичних ознак, притаманних саме йому» (Маевская, 2011: 278). В американській енциклопедії письменника знаходимо наступне визначення колонки: «Короткий газетний або журнальний матеріал, присвячений вузькому колу інтересів або обставинам у широкому розумінні, написаний зрозуміло та лаконічно, який має обсяг у 300-350 слів і з'являється регулярно (щодня, щотижня і т. д.) з обов'язковим вказанням імені автора» (Цит. за: Маевская, 2011: 279). Іспанський проф. Марія Iсус Касальс Карро (M. J. Carro Casals) стверджує наступне: «Дати визначення колонки можна «з різних кутів». Залежить від критерію, який береться за основу: їі положення в газеті, історичний контекст чи відчуття норми» (Цит. за: Маевская, 2011: 279). Дослідник відносить слово «колонка» до неологізмів, який утворився внаслідок метоні- 
мії (переносу частини - місця на шпальті газети на ціле). Цим неологізмом позначають підписану авторську статтю, яка публікується регулярно та займає визначене місце в газеті. Ба більше, «колонка займає стійке місце в жанровій системі не тільки як давно сформований спосіб написання журналістського тексту, але й у зв'язку з тим, що на місце колонки як способу короткого вираження власної думки більше ніхто не претендує» (Ярцева, 2009). Як бачимо, уявлення про колонку істотно різняться, тому у пропонованій статті спробуємо довести, що колонка - це нова жанрова форма у системі існуючих публіцистичних жанрів, яка характеризується низкою внутрішніх та зовнішніх ознак та володіє відповідними маркерами жанру.

Мета статті - запропонувати комплексний аналіз авторської колонки на прикладі колонки редактора як жанру професійно-непрофесійного валеологічного дискурсу (адресатом є експерт, а адресантом - широкий загал). Досягнення мети передбачає виконання наступних завдань: обгрунтувати правомірність виокремлення авторської колонки як окремого жанру й визначити його зовнішні та внутрішні ідентифікатори, запропонувати власну дефініцію даного явища та 3'ясувати його домінантні жанрові ознаки.

Виклад основного матеріалу. Матеріальною базою дослідження послугували 100 текстів колонок редакторів, які було відібрано 3 шести британських та північноамериканських глянцевих журналів (електронних версій), в яких висвітлюються питання ведення здорового способу життя. Ці тексти розміщувалися в таких рубриках: Editor's letter (Health\&Fitness, Natural Health, Shape), Editor's note (Vegetarian Times), From the editor's desk (Whole living), Inside information (Prevention). Як бачимо, назви рубрик різняться, але ця відмінність жодним чином не змінює комунікативного завдання колонки редактора, яке полягає у виділенні цікавих та вартих першочергової уваги, на думку автора, питань, висвітлених у випуску. Можна навіть провести паралелі між колонкою редактора та анотацією: обидві передають зміст і головні ідеї випуску та наукової статті, відповідно, у сконденсованому вигляді та готують читача до сприйняття тексту статей, налаштовуючи останнього на певні очікування.

Водночас колонка володіє низкою ознак, які сприяють іï однозначній ідентифікації. Серед них, услід за Ю. А. Гордєєвим, виокремлюємо оформлювальні (формальні) та змістові особливості [Гордеев, 2010]. До оформлювальних або зовнішніх ідентифікаторів колонки редактора належать: періодичність появи на сторінках жур- налу, постійне місце в номері, відносно сталий обсяг тексту, оснащення публікації візуальними вказівками на особистість автора, ім'я та підпис автора тексту. Очевидно, що періодичність появи колонки редактора знаходиться у прямій залежності від періодичності виходу самого журналу. У нашому випадку, вона з'являється один раз на місяць. У кожному випуску даний тип тексту спостерігаємо на перших сторінках випуску, що підтверджує тезу про комунікативне завдання даної колонки. Обсяг тексту колонок трохи різниться у залежності від видання, але його середній розмір становить 170-500 слів, що видається достатнім для ознайомлення зі змістом номеру, адже колонка покликана зацікавити і зорієнтувати. Характерно, що дані тексти не оформлені у вигляді вузьких, симетричних 3 обох країв колонок, навпаки, текст подано практично на всю ширину сторінки із помітною асиметрією в кінці рядків (виняток - дві колонки у Whole living). Проте, ця особливість демонструє характерну для сучасного стану жанрів тенденцію до дифузії, розмитості жанрових меж. Відтак, авторське бачення та політика редакції стають визначальними в питаннях оформлення матеріалу. Кожна публікація оснащена фото редактора, серед яких - портретні фото, в повний зріст, а також серії фото, які наче розповідають певну історію, доповнюючи одна одну та перегукуючись зі змістом колонки. На всіх фото редактори усміхнені, відкриті та позитивно налаштовані, що, своєю чергою, сприяє позитивному налаштуванню потенційного адресанта, довірі до автора. Щодо розміщення фото відносно тексту, то маємо наступне відсоткове співвідношення: вгорі зліва $-50 \%$, вгорі справа $-21 \%$, внизу зліва $16 \%$, вгорі посередині - $8 \%$ і внизу справа $-5 \%$. Як видно 3 наведених даних, більшість фото розміщені вгорі, і саме ліворуч, що також невипадково, адже читач одразу отримує можливість візуально «познайомитися» 3 автором та сформувати певні очікування від авторського повідомлення. Фото виконують ще одну прагматичну функцію - вони слугують орієнтиром, на який покладаються читачі, коли черговий раз відкривають улюблене видання. Тобто фото - це візитка автора, яка допомагає ідентифікувати його роботи та підтверджує відому нині тенденцію «читати не видання, а авторів», що, своєю чергою, робить перші популярними та успішними. Вкінці кожну колонку супроводжує ім'я автора та його підпис, які наче підкреслюють авторське право редактора та співвідносять фото з іменем. Після даних про автора можна зустріти адресу його інституційної 
пошти або ж редакції та навіть посилання на профіль у соцмережах, що демонструє відкритість, готовність до діалогу з аудиторією та спонукає до \%інтерактивності. Наприклад:

\section{- TALK TO ME!}

Email me at

askelizabeth@shape.com

with thoughts, questions,

and feedback. And

follow me on Instagram

@EGAEDITOR (Shape, 2016 (1/2): 12).

Окрім зовнішніх, для колонки редактора характерні й змістові або внутрішні особливості, які проявляються у своєрідному осмисленні автором питань здорового способу життя, які видаються цікавими авторові та покликані зацікавити читача, а також в текстовому поданні такого осмислення через зміст і композицію тексту, використання мовних засобів. Так як колонка редактора $\epsilon$ авторською колонкою, то іiі характеризує авторський стиль викладу матеріалу на противагу фактичному (хоча факти й присутні). Авторська колонка демонструє світоглядні позиції та у поєднанні з автобіографічними моментами й достовірними, вдало обіграними автором, даними досліджень утворює завершений медійний продукт. Умовно колонку редактора можна поділити на наступні блоки: заголовок (окрім Health\&Fitness), вступ, основна частина та висновок. Заголовки несуть значне комунікативне навантаження - у \%лаконічній формі мотивують діяти: Go for the goal (Shape, 2016 (1/2): 12), Ready, set, action! (Whole living, 2011 (1/2): 16), Happy new you (Natural Health, 2012 (12): 12), Do something! (Shape, 2016 (6): 10), Time for a fresh start (Whole living, 2012 (1/2): 10). Вступна частина найчастіше розпочинається 3 риторичних запитань, автобіографічних моментів інколи у поєднанні $з$ даними проведених досліджень. Апелюючи до досвіду читача, риторичні питання виконують потужну прагматичну функцію - змушують зупинитись, задуматись і відверто відповісти самому собі на очевидні питання (або знайти відповіді у номері):

- How well do you know your body? What does it need to perform at its best? (Health\&Fitness, 2011 (5): 6).

- What motivates you to exercise? Is it a favourite class, the thrill of beating your best running time or the body confidence you get from feeling fitter and stronger? (Health\&Fitness, 2011 (3): 6).

3 метою завоювання довіри споживача до свого тексту та поточного випуску в цілому, автор ділиться своїм життєвим досвідом. Досить часто цей досвід стає наслідком необхідності підтвердити інформацію, яка пропонується увазі адресанта. Наприклад:

- Until a few weeks ago, you, me, and everyone else thought fat melted off the body via sweat, but now two researchers have corrected the mistake: Turns out $84 \%$ of fat exits your mouth and nose through simple exhales. TRY THIS NOW: I'm counting exhales during my AM hike-runs. It's cool math: A thousand exhales take about a half hour. Given that 30 minutes burns about 350 calories for me, 3 exhales is the sound of me burning 1 calorie. I love knowing these breaths carry converted fat in the form of carbon dioxide. Very trippy and inspiring (Prevention, 2015 (3): 12).

В основній частині редактор наводить головні ідеї статей, в яких піднімаються важливі питання збереження здоров'я, із посиланням на їхню назву та номер сторінки у випуску. До прикладу:

$-<\ldots>$ Whether you need to spruce up your home (see "Green Your Cleaning Kit», page 24, for the best eco-friendly products), your body (check out "Kick-Starter», page 56, for a delicious way to detox from the inside out), your brain (turn to «Clutter: The Long Goodbye», page 74, for an account of how liberating it can be to empty out the attic), or all three of them, this issue is blooming with bright ideas and information you can really use (Whole living, 2010 (5): 10).

Незважаючи на авторський стиль викладу, редактор оперує низкою фактів, які грунтуються на результатах проведених досліджень, опитувань:

- For years, the Environmental Working Group has been keeping the definitive «Dirty Dozen» list of the 12 fruits and vegetables most likely to be contaminated with pesticides. Culled from USDA and FDA data and presented side-by-side with a list of "Clean 15» foods with the lowest pesticide risk, it is perhaps the most useful shopper's cheat sheet ever invented (Vegetarian Times, 2010 (9): 4).

Поряд з очевидною лаконічністю, тексти цього жанру вирізняються особливою глибиною поглядів на актуальну проблему. Яскравим та дещо літературним $є$ наступний уривок, в якому автор порівнює заняття бігом із подорожжю, якій властиві нотки несподіванки:

- Still there's more to running than the body benefits - much more. Running is, quite literally, a journey that always provides some elements of surprise. Maybe it's the way the light hits the trees one morning, or a fellow jogger who smiles and waves just because. On the trail is also a place to work through problems or process grief. As with any health endeavor, running is not so simple as be gauged by miles covered. If you've ever been at the finish line of a race, from a $5 \mathrm{~K}$ 
Кількісний розподіл вживання у тексті займенників I та II особи, дісслів у наказовому способі

\begin{tabular}{|l|c|c|c|c|c|c|c|}
\hline $\begin{array}{c}\text { Займенники/ } \\
\text { Наказовий спосіб }\end{array}$ & $\begin{array}{c}\text { Health\& } \\
\text { Fitness }\end{array}$ & $\begin{array}{c}\text { Natural } \\
\text { Health }\end{array}$ & Prevention & Shape & $\begin{array}{c}\text { Vegetarian } \\
\text { Times }\end{array}$ & $\begin{array}{c}\text { Whole } \\
\text { living }\end{array}$ & Paзом \\
\hline I, my & - & $\mathbf{1 4 4}$ & $\mathbf{4 9}$ & $\mathbf{2 2 0}$ & $\mathbf{4 7}$ & $\mathbf{2 3 9}$ & $\mathbf{6 9 9}$ \\
\hline We, our - «ми, наш (редакція)» & 10 & 61 & 40 & 83 & 73 & 91 & $\mathbf{3 5 8}$ \\
\hline We, our - «ми, наш (усі)» & 3 & 32 & 26 & 33 & - & 121 & $\mathbf{2 1 5}$ \\
\hline You, уоur & 50 & 100 & 54 & 152 & 85 & 199 & $\mathbf{6 4 0}$ \\
\hline Наказовий спосіб & 29 & 19 & 54 & 71 & 20 & 23 & $\mathbf{2 1 6}$ \\
\hline
\end{tabular}

to an entire 26.2-mile marathon, you know that the emotion in the air is palpable (Shape, 2016 (4): 12).

Останній абзац або його останні речення можна назвати умовним висновком. Тут адресат оперує загальними мотивуючими твердженнями, які покликані заохотити читача до реальних кроків, детальнішу «інструкцію» до яких можна знайти у відповідних статтях випуску:

- Here's to you getting the boostyou need, so you can wake up every day full of joy and excited to tackle whateverlife throws yourway (Natural Health, 2011(11): 10).

- Whenever you feel stuck or frustrated, remember that when it comes to health and fitness, the benefits are never singular; that whatever you're doing is going to reap surprise and unexpected rewards. So go for your goals, and when you do, remember there are a whole slew of new ones lining up right behind them (Shape, 2016 (1/2): 12).

$-<\ldots>$ Our air, like our water, is the legacy we leave our children.

I'm all for pooling our resources to make sure that legacy is a good one (Whole living, 2012 (4): 10).

В колонці редактора як авторському жанрі знаходимо значну кількість випадків використання особових та присвійних займенників у першій особі однини $(I, m y)$. Займенники першої особи множини зустрічаються у двох значеннях: 1) we - «ми»редакторський штат видання та 2) we - «ми»- усі, люди загалом. Оскільки цей жанр орієнтується на діалог із аудиторією, то поряд із займенниками першої особи часто зустрічаються перелічені займенники другої особи (уои, уоиг). Нерідкісними $\epsilon$ дієслова у наказовому способі, які виражають рекомендацію, пораду, заохочення, застереження, адресовані читачеві. У наступній таблиці наочно продемонстровано кількісні дані використання цих займенників та дієслів у наказовому способі у виданнях нашого дослідження (табл. 1).

Як бачимо, переважають займенники I та уои, що ще раз підтверджує той факт, що редакторська колонка демонструє авторське бачення, активно апелюючи до реципієнта. Колумніст використовує «я»-повідомлення з метою скоротити дистан- цію між собою та читачем, щоб розповісти про те, що цікаве і близьке їм обом, навіть більше - усім читачам. Тому частими є речення із займенником we («усі»), в яких адресат закликає до спільних зусиль у вирішенні чи покращенні ситуації: We're drinking less soda. We may be consuming fewer calories. And now, finally, this. Could it be time to be optimistic, not cynical, about improving our collective health? (Prevention, 2016 (2): 14).

Як показало корпусне дослідження на матеріалі текстів колонки редактора, авторська колонка характеризується єдністю змісту, стилю і композиції, а також виконує важливе комунікативне завдання. Однак, як влучно зауважує проф. Т. В. Яхонтова, «метою жанрового аналізу повинно бути як виявлення різноманітних типологічних характеристик жанрів, так і дослідження їх варіабельності, множинності маніфестацій у текстах» (Яхонтова, 2009: 125). Відтак, серед аналізованих зразків зустрічались такі, які частково не «вписувалися в загальну картину», але цьому знаходимо логічне пояснення - авторський підхід та соціокультурний контекст (британська та американська ментальність). Більшість виділених у ході дослідження ознак колонки редактора як прикладу авторської колонки можна вважати домінантними і визначальними у питанні ідентифікації останньої як самостійного жанру. Отже, на наше переконання, авторська колонка-це публіиистичний жанр, який з'являється регулярно, характеризується компактним обсягом, чітко вираженою авторською позицією, діалогічністю та інтерактивністю.

Висновки. Внаслідок зростаючого попиту не на новину, а на іiї оцінку, інтерпретацію, відбувається переоцінка жанрових цінностей. На сторінках преси дедалі рідше вдається відшукати «чисті» публіцистичні жанри, простежується тенденція до розмивання жанрових меж - жанрової дифу3iі. Авторська колонка як нова, нескута нормами форма «журналістики думок» - яскравий приклад медійного продукту, який відповідає сучасним тенденціям породження жанрів та ідентифікується як популярний жанр періодичних 3MI. 
На прикладі колонки редактора встановлено, що авторська колонка - повноцінний публіцистичний жанр, який характеризується єдністю змісту, стилю і композиції, високим ступенем інтимізації та персоналізації викладу, а також володіє низкою формальних та змістових ідентифікаторів. Серед його домінантних жанрових ознак виділя- ємо образ автор та його авторське бачення, оснащення публікації фото адресата, діалогічність викладу та орієнтацію на інтерактивність.

Водночас вимагають висвітлення механізми вербального впливу на поведінку і мислення реципієнта у валеологічній комунікації з позицій теорії дискурсу.

\section{СПИСОК ВИКОРИСТАНИХ ДЖЕРЕЛ}

1. Гордеев Ю. А. Жанровая специфика колонки в печатных СМИ. Жанровые метаморфозы в российской журналистике: тезисы IV Всероссийской научно-практической конференции г. Самара 18-19 марта 2010 2., Самара: Изд-во «Порто-принт», 2010. С. 22-23.

2. Журналістика: словник-довідник / авт.-уклад. І. Л. Михайлин. - К.: Академвидав, 2013. 320 с.

3.КройчикЛ.Е.Системажурналистскихжанров. Основытворческойдеятельностижурналиста. СПб.,2000.С. 125-167.

4. Маевская А. Ю. Колумнистика в глянцевых журналах. Вестник СПбГУ. Сер. 9. 2011. Вып. 2, С. $273-282$.

5. Тертычный А. А. Жанры периодической печати. М.: Аспект Пресс, 2000. 312 с.

6. Черникова Е. В. Азбука журналиста. М., 2009. 283 с.

7. Шостак М. Журналист и его произведение. М.: Генфальд, 1998. 95 с.

8. Ярцева С. С. Колонка в американской и испанской журналистике. Жанровая стратегия современных массмедиа: тезисы III Всероссийской научно-практической конференции г. Самара 19-20 марта 2009. Самара: Изд-во «Универс групп», 2009. С. 109.

9. Ярцева С. С. Колумнистика: история возникновения и перспективы развития: автореф. дисс. ... канд. филол. наук: 10.01.10. Воронеж: Воронеж. гос. ун-т, 2011. 22 с.

10. Яхонтова Т. В. Лінгвістична генологія наукової комунікації: монографія. Львів: Видавничий центр ЛНУ імені Івана Франка, 2009. 420 c.

11. Health\&Fitness. 2010. № 11, 12. 2011. № 2, 3, 5, 6. 2018. № 9. 2019. № 8, 12 .

12. Natural Health. 2010. № 12/1 (2011). 2011. № 2-12/1 (2012). 2012. № 2-6. 2015. № 4. 2016. № 4-6. 2017. № 1, 5-12. 2018. № 4, 8-11. 2019. № 1-7, 9-12.

13. Prevention. 2010. № 7, 9, 10. 2011. № 1-12. 2012. № 1-3. 2014. № 12. 2015. № 2-12. 2016. № 2-8, 10. 2017. № 1, 2, 7, 8, 10-12. 2018. № 1, 4-12. 2019. № 1-12.

14. Shape. 2010. № 7-12. 2011. № 2-12. 2012. № 1, 2, 5, 6. 2015. № 3, 6-8, 10-12. 2016. № 2-6, 9-12. 2017. № 1, 3, 4, 6, 9, 11, 12. 2018. № 3-7, 9-12. 2019. № 1, 3-7, 10-12.

15. Vegetarian Times. 2010. № 1-5, 7-12. 2011. № 1-12. 2012. № 1-6. 2014. № 12. 2015. № 2, 10, 12. 2016. № 2, 4, 9/10. 16. Whole living. 2010. № 3-7, 9-12. 2011. № 1, 3-12. 2012. № 2-6.

\section{REFERENCES}

1. Gordeev Ju. A. Zhanrovaja specifika kolonki v pechatnyh SMI. [Genre specifics of column in printed media]. Zhanrovye metamorfozy $v$ rossijskoj zhurnalistike: tezisy IV Vserossijskoj nauchno-prakticheskoj konferencii g. Samara 18-19 marta 2010 g., Samara: Publishing house "Porto-print", 2010. pp. 22-23 [in Russian].

2. Zhurnalistyka: [Journalism]: slovnyk-dovidnyk / avt.-uklad. I. L. Mykhailyn. - Kyiv: Akademvydav, 2013.320 p [in Ukrainian].

3. Krojchik L. E. Sistema zhurnalistskih zhanrov [System of journalistic genres]. Osnovy tvorcheskoj dejatel'nosti zhurnalista. St. Petersburg., 2000. pp. 125-167 [in Russian].

4. Maevskaja A. Ju. Kolumnistika v gljancevyh zhurnalah [Columnistics in glossy magazines]. Bulletin of St. Petersburg State University. Ser. 9. 2011. Vyp. 2, pp. 273-282 [in Russian].

5. Tertychnyj A. A. Zhanry periodicheskoj pechati [Genres of periodical press]. Moscow: Aspekt Press, 2000. 312 p. [in Russian].

6. Chernikova E. V. Azbuka zhurnalista [Journalist's alphabet]. Moscow, 2009. $283 \mathrm{p}$ [in Russian].

7. Shostak M. Zhurnalist i ego proizvedenie [Journalist and his work]. Moscow: Genfald, 1998. 95 p [in Russian].

8. Jarceva S. S. Kolonka v amerikanskoj i ispanskoj zhurnalistike [Column in American and Spanish journalism]. Zhanrovaja strategija sovremennyh mass-media: tezisy III Vserossijskoj nauchno-prakticheskoj konferencii g. Samara 19-20 marta 2009. Samara: Publishing house «Universe group», 2009. p. 109 [in Russian].

9. Jarceva S. S. Kolumnistika: istorija vozniknovenija i perspektivy razvitija [Columnistics: origin and prospects of development]: avtoref. diss. ... kand. filol. nauk: 10.01.10. Voronezh: Voronezh State University, 2011. $22 \mathrm{p}$ [in Russian].

10. Yakhontova T. V. Linhvistychna henolohiia naukovoi komunikatsii [Linguistic genology of scientific communication]: monohrafiia. Lviv: Publishing Centre of Ivan Franko National University of Lviv, 2009. 420 p [in Ukrainian].

11. Health\&Fitness. 2010. № 11, 12. 2011. № 2, 3, 5, 6. 2018. № 9. 2019. № 8, 12 .

12. Natural Health. 2010. № 12/1 (2011). 2011. № 2-12/1 (2012). 2012. № 2-6. 2015. № 4. 2016. № 4-6. 2017. № 1, 5-12. 2018. № 4, 8-11. 2019. № 1-7, 9-12.

13. Prevention. 2010. № 7, 9, 10. 2011. № 1-12. 2012. № 1-3. 2014. № 12. 2015. № 2-12. 2016. № 2-8, 10. 2017. № 1, 2, 7, 8, 10-12. 2018. № 1, 4-12. 2019. № 1-12.

14. Shape. 2010. № 7-12. 2011. № 2-12. 2012. № 1, 2, 5, 6. 2015. № 3, 6-8, 10-12. 2016. № 2-6, 9-12. 2017. № 1, 3, 4, 6, 9, 11, 12. 2018. № 3-7, 9-12. 2019. № 1, 3-7, 10-12.

15. Vegetarian Times. 2010. № 1-5, 7-12. 2011. № 1-12. 2012. № 1-6. 2014. № 12. 2015. № 2, 10, 12. 2016. № 2, 4, 9/10. 16. Whole living. 2010. № 3-7, 9-12. 2011. № 1, 3-12. 2012. № 2-6. 